\title{
Deconstruction the end of writing: 'Everything is a text, there is nothing outside context'
}

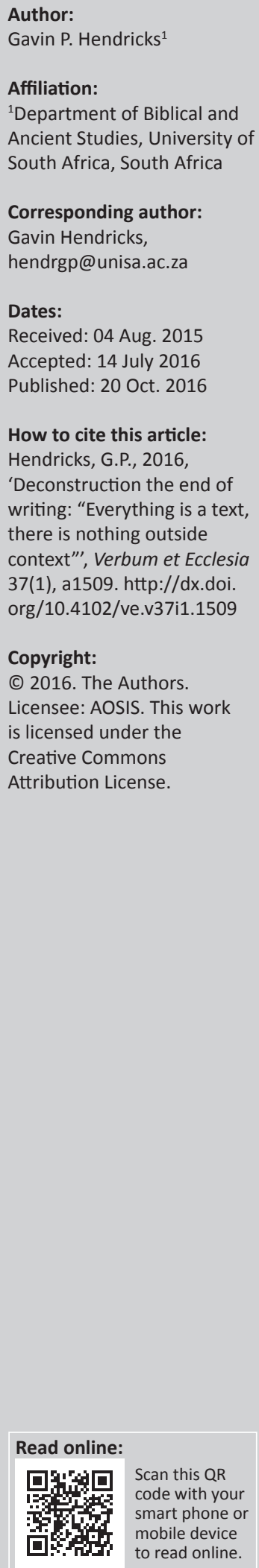

In this article, I read Derrida's critique of the 'sign' over against the challenges of the metaphysics of presence as featured in Western theology and philosophy. Derrida argues that logocentric interpretive interest in theology and philosophy is widely held and contradict by the West, as this somehow reveals the Western belief of the metaphysics of presence. He argues that the idea of metaphysics of presence which is strongly held in Christianity and Judaism is somehow privileged speech (Logos) over against writing which is seen as death and alienated from existential and transcendental reality. Derrida focuses on the reading of Saussure and how presence has been perceived over against writing in Western discourse in terms of the interpretation from Plato to Rousseau. Derrida prefers to deconstruct presence, which is perceived in Western theology and philosophy as truth and the ideal moment of pure, unmediated firstness. This article focuses on the reading of the work of Saussure, who has been greatly influential in the study of oral traditions, verbal arts and the interpretive interest of the sign. For Derrida writing has been suppressed by Western discourse for almost 400 years, as speech has been privileged over writing. The function of deconstruction is to deconstruct the binary opposition between speech and writing. Derrida provides clear examples of his deconstructive activity, which turns the text in traces of more text in opposing speech as unmediated firstness of presence. Derrida's critique of speech hopes to expose the dishonesty and false consciousness in a Western interpretive discourse that suppressed writing and perceived speech as presence. This relation is both oppositional and hierarchical, with writing as secondariness understood as a fall or lapse from firstness. For Derrida, 'there is nothing outside of the text'. In the original French, Derrida wrote: 'Il n'y a pas de hors-texte' [There is no outside-text]. Language is a constant movement of differences and everything acquires the instability and ambiguity inherent in language (Callinicos 2004). The implications of Derrida's reading based on his work Of Grammatology (1976) have impacted everything in the humanities and social sciences, including law, anthropology, linguistics and gender studies, as the meaning of the text is not only inscribed in the sign (signifier and the signified), but everything is a 'text' and meaning and representation are how we interpret it.

Intradisciplinary and/or interdisciplinary implications: Derrida sought to subvert the 'sign' in structuralism, as it opens the door to dialogue with the socially constructed 'Other' in relation to the 'sign' and the false consciousness construction of the text by the West. This challenges the existing interpretive paradigm and open oral and written dialogue of the text for the 'other' in terms of the meaning and representation of the oral text, the oral archival memory of the other, indigenous knowledge systems, African rituals, folklore, storytelling and verbal arts.

\section{Introduction}

Derrida sought to subvert the 'sign' in structuralism, as deconstruction opens the door for transdisciplinary, interdisciplinary and intertextual research, to dialogue with the socially constructed 'Other' in relation to the sign. For Bakhtin the rhetorical environment can be seen as plurality of the other's discourse, for if these other voices were not in some measure persuasive there would be no need for the new voice (dominant ideological interpretive interest) to compete with them, in declaring them unpersuasive (Tull 1999:168). For Bakhtin, the social world is made up of multiple voices, perspectives and subjective worlds. The other's response in dialogue can change one's owns consciousness or perspective and can produce actual social and political change. Dialogism as described by Bakhtin can create new interpretive interests and representations intertextually and interdisciplinary of meaning as the writers write in awareness of dialogue with readers and anticipate their responses (Tull 2000:70). Intertextuality and interdisciplinary implication in the reading of the sign in relation to Derrida and Bakhtin can open oral and written dialogue of the text for the socially constructed 'Other' in terms of the meaning and representation of the oral text, oral archival memory 
of the other, indigenous knowledge systems, African rituals, folklore, storytelling and verbal arts:

The text is taken up on an open network which is the very infinity of language. (Degenaar 1992:187)

Deconstruction, a theory about language and literature, was developed in the 1970s, in large part as a reaction to the primacy of French structuralism and a repressive academic and intellectual system that rigidly administered a unique and definitive interpretation of literary text. Deconstruction designates the philosophy of Jacques Derrida, which is a strict analysis of language in the philosophical and theological text. What most characterises deconstruction is its notion of textuality, a view of language as it exists not only in books but in speech, in history and in culture, especially the written language (Ellis 1989:84). For Derrida, there was 'nothing outside the text' (Derrida 1976:158).

Derrida argues not simply to reverse but to challenge from within the centring of meaning offered by the binary opposition (speech and/or writing) through which structuralist thinkers of the post-war period had claimed to uncover hidden meaning in language. Derrida insists that deconstruction is not a method, technique or species of critique. According to Derrida, deconstruction is a useful means of saying new things about the text. Derrida's close reading of Jean-Jacques Rousseau clearly shows the relation between writing and language, which Derrida marks with the expression of supplementation in the text. Writing can thus be seen as a 'dangerous supplement' (Rheinberger 2008:85). A 'supplement' is something that is secondary, a sign of a sign, taking the place of speech already significant (Derrida 1976:281). The ongoing replacement of meaning and representation of the text is through traces of more text. Derrida's deconstructive moves are interested in the dismantling of conceptual opposition, the taking apart of hierarchical systems of thought, which can then be reinscribed within a different order of textual signification. Deconstruction is vigilantly seeking out aporias, blind spots or moments of self-contradiction in the text that involuntarily betray the tension between rhetoric and logic, what the text says and what it is intended to mean (Norris 1987:19).

Derrida is careful to add: 'But undoing, decomposing and desedimenting of structures was not a negative operation' (Derrida 1985:85-87). Deconstruction is not destruction, in other words, but rather the dismantling of cultural, philosophical, institutional structures that starts from textual. Every system is a social construction, something that has been assembled, and construction entails exclusions. Deconstruction seeks out those points or cracks in the system, where it disguises the fact of its incompleteness, its failure to cohere as a self-contained whole. In locating these points and applying a kind of authority to them, one is able to deconstruct the system (Derrida 1986:151). Deconstruction distrusts all systems (applies a hermeneutics of suspicion).

Deconstruction views language as a play of differences and produces a strategy that enables one to discover the powerful role played by language in our thinking. 'Play' for Derrida is the 'disruption of presence' that he argues is the illusionary metaphysics of presence, around which Western philosophical thought rests. The metaphysics of presence is premised on the belief that, firstly, being is manifested by the presence of bodies and things; secondly, being is 'more present' and thirdly that the concept of being excludes absence. Derrida, in relating to Saussure, argues that being itself is constituted by that which is absent (Shepherd 2007:229). Deconstruction's major objective is to take the text apart and point out the behaviour of figurative language, following which the elements are put together in a totally different way. Deconstruction is indebted to Nietzsche for teaching the mind how to dance by acknowledging the metaphorical power of language and the joyful affirmation play of the world.

In 'Structure, Sign, and Play', Derrida (1978) articulates Nietzsche's perspective as:

... the joyous affirmation of the play of the world and of the innocence of becoming, the affirmation of a world of signs without fault, without truth, and without origin which is offered to an active interpretation. (pp. 278-293)

It rejects the notion of deep structure in the text as well as the early metaphysical view of Nietzsche that God, the primordial one, plays with the world. The death of God (in JudeoChristianity referred to as 'Logos') is important in Western culture, for it liberates man from otherworldly fetters and leads to the discovery of the power of human imagination in giving meaning through art and aesthetics (Degenaar 1992:188).

In Twilight of the Idols, Nietzsche (quoted by Turner) says that although God (Logos) is dead in Western culture he is very much alive in language and the construction of the text. Nietzsche laments, 'I fear we are not getting rid of God (Logos) because we still believe in grammar', thereby expressing, perhaps seminally for much of the French interpretation of Nietzsche, logophobia, fear of language, because it torments him with theological paradox (Turner 2004:150). Where grammar stands for the belief in a simple correspondence between language and the world it represents, language not only influences the way we understand the world but also is a clear expression of the primordial essence of Logos in relating to the Imago Dei [image of God] in humankind. This is a formative aspect of Derrida's deconstruction of logocentrism.

Deconstruction takes elements of the text apart, points out the behaviour and figurative language and interprets the sign in another way. It is a close reading of the text, albeit a negative one. Derrida approaches the text through double reading. The purpose is not to demolish or displace conventional reading but to prove moments of self-contradiction in the text. Deconstruction can only take place within a dominant interpretation, rather than from 'outside'. Deconstruction is a speculative enterprise and can be seen as purely as relativism (Shepherd 2007:235-236). 
Derrida's sceptic position shows the aporias or blind spots and contradictions in the dyadic sign model of structuralism. According to Chandler, Saussure defines the 'sign' as being composed of a signifier and the signified. Linguist and literary scholars describe the 'signifier' as the form that the sign takes and the 'signified' as the concept it refers to. For Saussure, both the signifier (the sound pattern) and the signified (the concept) are purely psychological. A sign is a combination of a signifier with the signified, whereas Saussure focuses on the linguistic sign as phonocentric privilege in the Western classical tradition of reason. Derrida sees writing as separate, secondary, dependent on the sign system to produce meaning and representation. For Saussure, writing relates to speech as the signifier and the signified, but Derrida opposes Saussure by indicating that writing is a sign of a sign (Chandler 2007:14-16).

For Derrida structuralism was an empiricist reaction to the interpretative projects of the New Criticism movement, and it explained referent meaning as the centre of a symbolic system or structure. Derrida suggests that the dyadic sign model (sign and signifier) of Saussure is responsible for generating the aporias of structuralism. He further objects to a tradition that presents a simplistic, deterministic view of human signification (Culler 1982:28). Derrida's critique is governed by the metaphor of generalised (archē) writing. Writing is the structure and the process that makes possible the dynamic character of language. For Derrida (in Spivak 1976:14), writing is considered to be exterior to language, as he further argues that:

$[T]$ he exteriority of the signifier is the exteriority of writing in general, and I shall try to show later that there is no linguistic sign before writing (no Logos or metaphysic of presence). (p. 14)

Derrida questions Saussure's two-faced sign, the maintenance of the rigorous distinction between the signifier and the signified (Derrida 1981:19). This leaves open the possibility of thinking a concept signified in and of itself, a concept simply present for thought, independent of a relationship to a system of signifiers. Derrida's term for such a concept is a 'transcendental signified', which in essence refer to no signifier (Derrida 1981:19). For him, the entire history of the West bespeaks the 'powerful irrepressible desire' for such a signified, an order of being that would be fundamental and permanent and place a reassuring end to the reference from sign to sign (Derrida 1976:49).

For Derrida, the transcendental signifier (Logos) has always had a special relationship to presence for the West. In Structure, Sign, and Play (Derrida 1966), he claims that all the names that related to fundamentals have always signified a changeless presence. This is carefully seen in a list of Greek terms with a theological and philosophical reverberation, for example eidos [Platonic essence], arche [beginning, originfounding principle], aletheia [truth] and Logos [Word, reason] (Derrida 1966:279-280).

For Derrida, the history of the sign in Western theology and philosophy, the signified, the meaning we attach to the signifier, came to take on reality in its own right. For Derrida, the written text possesses meaningful status in itself. According to him, one falls into 'naive objectivism' in attaching transcendental significance and ontological status to the referent of language. In language the signified is assumed to be imaginable and thinkable in the present of the divine Logos in its breadth (words in space) (Derrida 1976:61-73). The desire to ascribe transcendental significance to the signified can be called 'logocentric metaphysics'. To understand Derrida's logocentric critique there is a need to first give a general overview on structuralism hermeneutics.

\section{Structuralism hermeneutics of the sign}

At the beginning of the twentieth century, Saussure contributed to our understanding of Semiotics. Crucial to Derrida's philosophical and literary project on the sign is a strategic recasting of the structural linguistics of Ferdinand Saussure. Hawkes (1977:123) quotes Saussure, defining 'semiology as a science that studies the life within society'. The linguistic sign unites, not a thing and a name, but a concept and a sound image. The latter is not the material sound, a purely physical thing, but the psychological imprint of the sound, the impression it makes on our senses (Cahoone 1996:178).

Structuralism has been very influential in the study of oral tradition and verbal arts. Drawing on Saussurian literary and linguistic theory, structuralism focuses on the structure of the item being studied (Finnegan 1992:36). Structuralism is appealing to some critics because it adds a certain objectivity, a scientific objectivity, to the realm of literary studies. The scientific objectivity is achieved by subordinating parole [speaking] to langue [language] (Hawkes 1977:123).

In structuralism, the individuality of the text disappears as it looks at systems, patterns and structures. In looking at stories, hymns and folklore, the author is cancelled out since the text is a function of a system, not an individual. The Romantic humanist model holds that the author is the origin of the text, its creator. Structuralism further argues that any piece of writing or signifying system has no origin and that authors inhabit pre-existing language structures that enable them to make any story. Man in generic form inhabits a structure that enables him to speak (Hawkes 1977:123).

Structuralism further provides a methodological framework for the semantic representation of signs, which constitutes the signified of the literary work of art. Saussure further regards the relationship between the signifier and the signified as arbitrary. Hawkes (1977) explains the nature of the sign in the following way:

The bond between the signifier and the signified is arbitrary. That result from the associating of the signifier with the signified, I can simply say the linguistic sign is arbitrary. (p. 67)

Culler (1981:22) shows that the theory proposed by Saussure clarifies the system or language that underlies the literary work of art and that makes the artefact a meaningful 
production, which he called 'speaking'. Barthes regards the former, langue, as the language, which is both the institution and the system. In contrast to language, Barthes (1977:14) defines 'parole' or 'speech' as 'essentially an individual act of selection and actualization'.

Saussure insists that language is a differential network of meaning. According to Saussure, a linguistic sign is not a link between a thing and a name, but between a concept and a sound pattern (a sound as processed by a hearer). Saussure replaces the terms 'sound pattern' and 'concept' with 'signifier' and 'signified' and to keep in one's memory the term 'sign' and to designate the combination of the two. The signifier would be the material acoustic component of the sign as it registers in the mind of the hearer (e.g. the sound ' $d \log ^{\prime}$ ), whereas the signified would be the sign's conceptual framework (the concept 'tree') (Bally \& Sechehaye 1986:65-67).

Saussure argues that linguistics could be placed on a scientific basis only by adopting the synchronic approach in treating language as a network of structural relations. Saussure finds it necessary to make a distinction between the isolated speech act or utterance (parole) and the general system of articulate relationships from which it is derived (la language). This act of divorce is further sanctioned by the arbitrary nature of the sign. For Saussure, there cannot exist a natural relation between the signifier and the signified, the word as a material token of meaning and the concept it conveys (Norris 1982:25).

The distinction between language (langue) and speech (parole) is very important for Saussure, as it has been taken up in connexion with the form criticism of the gospels by Erhardt Güttgemanns. For Saussure language must not be confused with speech or actual speaking (parole). According to Marshall (1979):

Language is a social product of the faculty of speech and a collection of necessary formalities that have been adopted by a social body to permit individuals to exercise that faculty. (p. 88)

It is inherent within a community and it is the sum total of the word images that are stored in the minds of all individuals. It is a storehouse filled with images by members of a given community. Language is not complete in any individual speaker because it exists perfectly only within a collective (Marshall 1979:88).

Lévi-Strauss in the reading of Rousseau in his 'Essay on the Origins of Language' (1986) argues that the dawn of writing signalled the downfall of both language and fully human societies. Writing brought with itself a moment in which social inequalities and hierarchies appeared. For Rousseau, before the event of writing, humans lived in communities based on equity and sharing. With the advent of writing, power became supreme in the hands of those who were able to write and the accumulated knowledge it made possible. Norris (1987) as quoted by Shepherd (2007:230) sees two worlds, a prewriting natural world of speech, self-presence and social fairness, and another postwriting world, a social world rooted in unfairness, inequality and violence. LéviStrauss' distinction between those societies that are able to write and those that have no knowledge of writing is grounded in the empirical bedrock of Saussure's binary distinction between language (speech as an immediate presence) and writing (once removed from the sign of a sign). Thus, Derrida (in the work of Shepherd 2007) sees the separation of writing and speech by Lévi-Strauss as antiethnocentrism, whereas the other becomes pure and noble. He sees the West as the source of all evil and corruption. For Derrida writing needs to be defined more broadly and not only as a linear and phonetic notation on paper. Most communities can be seen as practising some form of this, as evidence of writing is already evident in their customs, culture, traditions and social hierarchy (Shepherd 2007:230).

Parole refers to the actual act of speaking. For Güttegemanns cited by Marshall, the speech of an individual is objectified in written form, for only an individual can do the actual writing. On the other hand, written paroles (speech) reflect the oral tradition of the language in that community. For Güttegemanns, language and parole (speech) need to be kept apart; the written word differs from that of individual speech, which forms part of the oral forms of language of a social community (Marshall 1979:89).

For Saussure (quoted by Bally \& Sechehaye 1986:66) the moment we consider the sign as a whole, we encounter something that is positive in its own domain. Although the signified and signifier are each in isolation, purely differential and negative, their combination is in fact of a positive nature. The moment we compare one sign with another as a positive combination, the term 'differences' should be dropped. It is no longer appropriate. The following term only remains suitable for comparisons between sound patterns or between ideas (e.g. written vs. oral). The two signs each comprise signification, whereas as signal are not different from each other but only distinct. For Saussure the signified, his term for 'concept', shows that the signifier (or sound pattern) is already sound as mentally processed, the hearer's psychological impression of a sound (Bally \& Sechehaye 1986:66).

Structuralism argues that the structure of language itself produces 'reality'. That homo sapiens (humans) can think only through language and, therefore, our perceptions of reality are determined by the structure of language. The source of meaning is not an individual's experiences or being but signs and grammar that govern language. Rather than seeing the individual as the centre of meaning, structuralism places the structure at the centre. It is the structure that originates or produces meaning, not the individual self. Meaning does not come from individuals but from the socially constructed system that governs what any individual can do (Klages 2012:2).

Structuralism has been criticised for de-emphasising local meaning, performance, context or human interaction. 
Structure remains a socially constructed phenomenon and the existence of language is not an invisible social reality but dialogic (interaction between humans) shapes and constructs, meaning and representations of reality. This is where deconstruction begins. The leading person in deconstruction, Jacques Derrida, looks at philosophy and theology through the eyes of Western metaphysics. Derrida's objective is to see whether any system posits a centre, a point from which everything comes from and to which everything refers or returns. For Derrida this rests on the eternal Logos that coexists with YHWH (יהוה) or God at the beginning of creation. This process focuses on deconstruction as method or technique in relation to the sign.

\section{Derrida's critique of the sign}

Saussure provided Derrida (1977) with a theory of language that enabled him to contest the historical determination of Being (or trancendental Logos as existential presence in the world) as presence. It was at this point that Derrida launched an attack on structuralism that attached the meaning of the sign to the Western metaphysics of presence. Derrida argues that Saussure's attitude to privileged spoken language as opposed to written language can be seen as a false construction of the Western metaphysics of presence. Derrida discovers a binary opposition between spoken and written language at the heart of the Western metaphysics of presence and a weakness of a centre opposition between speech and writing that needs to be deconstructed. Writing is treated as secondary and always dependent on the primary reality of speech, a sense that a speaker's presence is behind his word (Derrida 1977:27-73). Derrida has metaphysics (any science of presence) as his target. Derrida argues that any claim to escape from metaphysics remains flawed since no one can escape the limits of language. Derrida further argues that the Nietzschean critique of metaphysics, the Freudian critique of self-presence and Heidegger's claim of the destruction of metaphysics are forever trapped in a vicious circle. This circle 'describes the form of the relation between the history of metaphysics and the destruction of the history of methaphysics'. For Derrida this inescapability lies in the reality that the only language available is the language of philosophy (Shepherd 2007:228-229).

For Derrida, Saussure's language is a system of differences without positive terms. Language is a system that is created by negative signifiers put together. When the negatives are put together a positive is created, because of its relationship to something that it is not, from which it differs, and which itself cannot be present (Derrida 1982:13). Différance enables meaning. For 'then meaning is present, and presence itself can mean what it meant for Western metaphysics, only as an effect of "différance," the continual deference of meaning' (Derrida 1982:13). Derrida regards the ontological structure of structuralism a centre, a fixed origin. Names were given to this steadfast centre, including essence, existence, being, truth, God and man. Derrida rejects the idea of a transcendental signifier or a centre in the construction of language because it only substantiates the false belief and sophistry of the West and the immediacy of presence in speech (Berman 1988:201). This coincides with the work of Roland Barthes in 'The Death of the Author' (1967), of which Derrida and Foucault engage differently with the question of authorship. For Foucault (1977:116), the 'writing of our day has freed itself from the necessity of "expression"; it only refers to itself, yet it is not restricted to the confines of interiority'. For Derrida's (1982:13) language, texts need not refer to an external reality as metaphysically or ontotheologically present. Foucault, in response to Derrida and Barthes, states that if the author is truly dead, no identifiable subjectivity emerges from an authored text on the part of either the authors or characters. For Foucault, the death of the author has become too absolute, unmindful of the genetic implications of their own claims. Foucault critiques Derrida's concept of écriture. For Foucault, Derrida 'has transposed the empirical characteristics of an author to transcendental anonymity'. For Derrida, there is no longer an author who writes, but a play of signs that point to an ever-shifting and deferring origin and a constant differentiation of meaning through the arch conditioning of différance (Calcagno 2009:36-38; Derrida 1982:13).

Différance according to Derrida is an anarchic concept that makes language - as a play of signifiers - possible. Différance is typically what is involved in writing; this generalises the notion of writing that breaks down the entire logic of the sign (Derrida 1977:172). Before différance, all Western conceptual schemes relied on one form or another of a transcendental signifier. The transcendental signifier is any metaphysical, hierarchical principle that presumes to determine which constructions are 'natural' or 'proper'. Examples of transcendental signifiers include truth, Allah, God, Yahweh, reason and Being. Différance is the alternative to and escape from the logic of a transcendental signifier.

Derrida insisted that Being is produced as history only through the power of the eternal Logos, which underpins the bedrock of Western metaphysics, and that there is nothing outside the text that indicates 'the difference between signifier and signified is nothing'. The more the signifier signifies nothing, the more indestructible it is. For Heidegger, being the eternal Logos emerges as knowable only in language, and it is made present by words and hidden in the midst of them, a simultaneous revelation and concealment (Spivak 1976:23). In Derrida's discussion in Speech and Phenomena $(1967,1973)$ the whole idea of 'logocentrism' emerges in the work of Heidegger. Logos can be seen as reality and existence and Homo sapiens (humans) can interface with an existential (experiential) immediacy and directness, which speech, presumed to be the expression of its own immediacy, captures and transmits (Berman 1988:202). Derrida cannot accept such belief and that there could never have been 'a purity of sensory language'. This is a language construction that determines the construction of meaning and representation of reality. There is no language that is alien to this history (Royle 1995:23). There is nothing outside the text or nothing outside context. 
Derrida argues that the reading of the text should free itself, in its axis, from the classical categories of history, from the history of ideas and literature of the West that imprisons the text. The history of truth has always been a debasement of writing and its repression outside full speech. For Derrida writing opens the field of history (Derrida 1976:1xxxix-4). Writing is a means of reconstructing the social universe.

Derrida views this binary opposition between parole and language as a great tension between the meaning and representation of reality. For the structuralist this can be seen as an unavoidable binary opposition between speech and writing. Barthes (1967) quoted:

A language does not exist properly except in the speaking mass; One cannot handle speech except by drawing on language. But conversely, a language is possible only starting from speech; historically, speech phenomena always precede language phenomena (it is speech which makes language evolve), and genetically, a language is constituted by the individual through his learning from the environmental speech. (p. 16)

For Barthes, language is the product and instrument of speech and the relationship is always dialectical (hearer and speaker). This means that individual speech is raised above the system of meaning. For Derrida (1976), there is a fundamental blindness in the Saussurian text because it represses writing in the language system.

This distinction by Saussure between parole and language, compared to Eco's (1976:8) distinction between signification and communication, defines 'signification' as 'a theory of codes' and 'communication' as 'a theory of sign production'. For him, every act of communication between human beings presupposes a signification system as its necessary condition. There are two key points to the idea of deconstruction. Firstly, we are still going to look at the systems or structures of language, rather than individual concrete practices, and all systems and structures have a centre, the point of origin, the thing that created the system in the very first place. Secondly, all systems or structures are created of binary pairs or oppositions (oral and/or written) (Canfield 1993:24).

Derrida states that such systems are always built upon the basic units of structural analyses. The basic unit is the binary opposition or pair, and in that system one part of the binary pair is always more important than the other; one term is marked as positive and the other negative. Hence the binary pair - speech and/or written speech - is what Western research or philosophy privilege whereas written language is subordinated to speech. Derrida further argues that all binary pairs work this way, for example, light/darkness, white/black, masculine/feminine. In the Western culture or tradition, the first term is always valued or privileged over the second (Canfield 1993:24). Speech in Western theology and philosophy becomes privileged because it is always associated with transcendental presence and truth. For there to be a spoken language, somebody has to be present to be speaking.
Derrida's deconstruction of Western thinkers from Plato to Martin Heidegger attacks what he calls 'logocentrism', the human habit of assigning truth to the biblical Logos (Jn 1:1) or spoken language, the voice of Western reason, the Word of God in the Johannine narrative. Derrida finds that logocentrism generates and depends on a framework of two-term oppositions that are basic to Western thinking and tradition, such as being/non-being, presence/ absence, white/black and oral/written. In the logocentric epistemological system, the first term of each pair is the stronger (e.g. oral/written). Derrida (1976:11) is critical about these hierarchical polarities and seeks to take language apart by reversing their order and displacing them, and thus transforming each of these privileged terms in the binary constructions by putting them in a slightly different position within a word group or by substituting words in other languages that look and sound alike but are different.

The subject of Derrida's discussion in Of Grammatology and the principle source of his distress is the referential paradigm or centred linearity of language. Text-centrism found its philosophical self-justification in the work of Jacques Derrida. In 1976, Derrida delivered in Of Grammatology, an uncompromising critique of logocentrism. He viewed it as the root cause of logocentrism's interpretive interest of the West. Nowhere does he find referentiality more subtle than in the linguistic, theological concept of the sign. The linguistic sign is defined by the signifier and the signified. The signifier constitutes the visible marks (written text) committed to stone, papyrus or paper, whereas the signified refers to the so-called meaning we attach to them. The referential paradigm treats the written language as exterior and the referents, signified as having real meaning. This is for Derrida a principle of distress. The linguistic sign is defined by the signifier and the signified. The signifier constitutes the visible marks committed to paper and the signified is the so-called meaning we attached to it (Derrida 1976:13). For Derrida, the Western tradition - from Plato to Stoicism, Augustine's to Ferdinand Saussure's linguistic sign is defined by the signifier and signified and the transcendental to meaning attached to the text which privilege speech over writing. The 'signifier' constitutes written or visible words on paper, whereas the 'signified' refers to the meaning we attached to it (Kelber 1990:123).

Jacques Derrida's grammatological critique of logocentrism is strongly influenced through his Jewish background by the oral Torah (dabhar), which results in a contention between the word as text (signifier) and the word in space (signified), the metaphysics of presence (time and space) in the construction of meaning and representation of text. Logocentrism, ' $[i] \mathrm{n}$ the beginning was the Word' (Jn 1:1), is the belief that knowledge is rooted in a primeval language given by God to humans. God (or the other transcendental signifier: the Idea, the great Spirit, the Self, etc.) acts as a foundation for all of our thought, language and actions. Logos is the truth whose manifestation is in the world. He is the foundation for the binaries by which we think 
(e.g. orality and literacy; life and death; good and evil) (Evans 1991:xx1). This binary oppression between the written word (chirographically constructed) and the spoken word (Logos as the metaphysics of presence) in the critique of Derrida can be seen as the key to understanding his violent attack on the Western metaphysics of presence, which favoured speech over writing as method and technique.

Centred linearity is the progress of the discourse of the privilege of presence' in the immediacy of spoken or oral signifiers. Aristotle (384-322 BC) wrote, 'Spoken words are the symbols of the mental experience and the written words are symbols of spoken words' (Derrida 1976:30). For Derrida, Logos in the biblical text is closer to the signified, more present in the experience of signification. The distinction between the signifier and the signified is in itself an arbitrary one because the signified already functions as a signifier. The written word, therefore, is always implicated as twice removed from 'constitutive meaning'; it is simply a phonetic representation of what has been spoken to refer to what is (Allison 1973:11). The privilege of speech is, in fact, the very origin of the notion of the signifier.

Derrida further argues and speculates on the end of what he calls 'linear writing', which has been the same for 4000 years, through its triumph over non-linear writing, which originated in the West. For Derrida linear writing 'creates' the ideal of history: 'the unfolding of presence' (1976:106). In contrast, non-linear writing, which Derrida calls 'mythographic' writing, allows a kind of technical, artistic, religious and economic unity that linear writing disrupts. To regain access to this unity, we must de-sediment 4000 years of linear writing. For Derrida, the process of linear writing has been ingrained in Western thought, so much so that Western thinkers can no longer see it. Rather than a form of thought, it has been thought, 'meditation upon writing and the deconstruction of the history of philosophy has become inseparable' (Derrida 1980:106). Though the end of linear writing would indeed be the end of the book, non-linear writing may still allow itself to be encased inside of the book, and that is how the limits of Western metaphysical discourse have always been in place in theological and philosophical discourse of the written text (Derrida 1976:106).

The idea is that the spoken Logos in the biblical text of the Johannine Gospel guarantees the existence of somebody doing the speaking, as there exists a real self that is the origin of what is being said. Derrida calls this idea of the self that has to be there to speak, a part of metaphysics, the presence. The idea of being, or presence, is central to all systems of Western reasoning and epistemological tradition from Plato to Descartes. Presence is part of the binary opposition to presence/absence, oral/ written, and presence is always favoured over absence or the written word. Speech becomes associated with presence, and both are favoured over writing as an absence. This privilege of speech associated with presence is what Derrida calls 'logocentrism' (Canfield 1993:24).
The Western tradition of the metaphysics of presence reveals the assumption that the physical presence of a speaker authenticates his speech. What would be more natural than to favour speech? As I speak my words appear to be one with my thoughts. My meaning seems to be fully present, both to me and to my hearer. At such moments the voice, the breath (Ruach-spirit) to be consciousness itself, presents itself. Speaking would then precede writing (the sign of a sign) since the writer is not present at the reading of his text to authenticate it. Spoken language is assumed to be directly related to thought, writing a supplement to the spoken language, standing in for it (Moore 1994:122). This is the result of phonocentrism, the valorisation of speech over writing.

Derrida (1976) proposes that such a project begins with the examination of the paradox of the immediacy of speech and the nevertheless privileged place of writing as the first metaphor':

Reading and writing, the production or the interpretation of signs, the text in general as the fabric of signs, allow themselves to be confined within secondariness. They are preceded by a truth, or a meaning already constituted by and with the element of the Logos. Even when the thing, the 'referent', is not immediately related to the Logos of a creator God where it began of being spoken/thought sense, the signified has, at any rate, an immediate relationship with the Logos in general (finite or infinite), and a mediated one with the signifier, that is to say with the exteriority of writing. (p. 15)

Writing is both distanced from 'signification' and equal to 'meaning' at the same stroke. For Klages (2012), what Derrida does in deconstruction is to look at the binary opposition between (speech and/or writing), the fundamental unit of the structures or systems and how it function within a system. He points out that a binary opposition is algebraic (e.g. $a=b$, a equals not $-b$ ) and that the two terms cannot exist without reference to the other. Speech or spoken Logos as presence is defined as the absence of writing. Derrida does not seek to reverse the hierarchies implied in the binary pairs, writing favoured over speech, the unconscious over the conscious, feminine over masculine. Rather, deconstruction seeks to erase the boundaries (the slash) between the opposites and to show that the values implied by the opposites are not fixed but socially created and constructed (Klages 2012:2-5).

\section{What is deconstructive activity?}

Basic to the whole approach of deconstruction is that it is viewed as a strategy. In no sense is it a method, but it adopts a specific approach to the understanding and reading of the text. The text must not be thought of as a defined object. In other words, the text is experienced only in an activity, production or traces of more text (Barthes 1979b:74-75).

For Barthes (1977:77), every text being the intertext of another text. Deconstruction liberates the text entirely from the hegemony of an author. For Derrida once, a work has been written, the text acquires an independent existence. The text 
is read without the father's signature (Barthes 1979:77-78). Postmodern feminists, who rely on a number of texts (written, visual and performative text), have strongly argued with authors like Barthes (1977), as well as Kristeva (1980), that the text cannot operate or be produced in isolation and must be seen as an architectural intention of intertextuality in postmodernism, as opposed to focusing on a text in isolation, which sometimes can be referred to as 'logocentrism' (Joyce 2012:65). For Saussure, 'the signified remain inseparable from the signifier, that the signified and the signifier are the two sides of the one and the same production'. The privileging of speech over writing is what Saussure called 'logocentrism', the 'phonic substance' of the breath of the voice tying the sign to the aspirations of the phone as 'the regulatory model', 'the pattern' for general semiology (Trifonas 2001:326-327). For Joyce, the term 'intertextuality' in the work of Kristeva and another postmodern feminist theorist describes the inevitability of textual relatedness and interconnectedness. The impact of one text upon another has radiating effects and therefore all texts can be considered as repetitions of other texts. Upon recognising every text as part of a web or mosaic of an intertext, the possibility of originality, exclusivity and inimitability become unachievable (Joyce 2012:65).

Deconstruction liberates the text entirely from the hegemony of an author. Once a work has been written, the text acquires an independent existence. For Barthes, the text is read without the father's signature (Barthes 1979b:78). Instead of uncovering the hidden meaning in the text, deconstruction seeks to show how the text disseminates. Meaning is not to be discovered in the text. Meaning is deferred from one text to another. Traces of meaning appear in the text and the reader (trained) can see how these traces of meaning appear and disappear and how meaning is ultimately deferred (Taylor 1984:179). Derrida argues that the text can be seen as a system of signs and that there were no extra-textual truths or extra-linguistic facts to refer to. There was nothing 'out there' but a play of signs (Joyce 2012:65).

Derrida's method of deconstructive reading focuses on the rhetorical operations of the text. This process of uncovering rhetorical operations in binary structure of philosophical text can be seen as the bedrock of deconstruction. Derrida's opposition is concerned with writing as a supplement to speech. Plato, Rousseau, Saussure and Levi-Strauss have denigrated the written word and valorised speech. Derrida noticed a curious pattern in Western history as a neologism of philosophy and theology is to belittle the written word while elevating the spoken word. For Trifonas (2001:326), this can be seen as a product of representational understanding in terms of an economy of signification.

Derrida names this hierarchy of speech and writing, where speech is the prior and privileged term 'phonocentrism' (Culler 1982:92). Phonocentrism understands the idea of language as representing pure thought transparently, with little or no effect on the thought itself. Oral representation comes closest to that ideal. Written language, with its materially visible signs that can be repeated at a distance from the original author, threatens to distort the 'original meaning' (Culler 1982:92). Speech, as opposed to writing, comes closest to the ideal of transparently presenting thought and reason. Phonocentrism, which 'treats writing as a representation of speech and puts the speech in a direct and natural relationship with meaning', is deeply entangled with the Western metaphysics of presence (Culler 1982:92). The objective of speech as the representation of pure thought depends upon the assumption that such pure thought exists in the first place in the philosophical text. This assumption is called 'logocentrism', which is the orientation towards an order of meaning, thought, truth, reason, logic and the word, as it is conceived in existing in itself, as a foundation for 'truth' (Culler 1982:93-94).

Derrida's deconstruction remains a rigorous form of interrogation, because the 'speaking subject', when he or she speaks, must speak the language of reason. Here the basic method of deconstruction is to find a binary opposition (e.g. speech and/or writing) and show how each term, rather than being the polar opposite of its paired term, is actually part of it. Then the structure or opposition that kept them apart collapses. Ultimately, you cannot tell which is which and the idea of binary opposition loses its meaning or is put into a play (traces of textual meaning). This method is called 'deconstruction' because it is a combination of constructing meaning and deconstructing the metaphysics of presence from the text. The idea is that you do not simply construct a new system of binaries, with the previously subordinated term on top, nor do you destroy the old system. Rather, you deconstruct the old system by showing how the basic units of structuration (the binary pairs and their rules for combination) contradict their own logic (Klages 2012:5).

\section{Conclusion}

For Derrida the history of the 'sign', signifying the meaning we attach to the signifier, has taken on its own reality and meaning in Western philosophy and theology. Central to the work of deconstruction is the idea of differance, which prevents the possibility of theorising a transcendental signifier (e.g. God, Spirit, Being or truth), as no historical work of God can survive the deconstructive framework because meaning and representation always defer which at large destroys the empirical historicity of theology. Caputo clearly indicates that differance is not God and that the God of negative theology is a transcendental ulteriority, whereas différance is a quasitranscendental anteriority. Deconstruction can be seen as negative theology; deconstruction and différance are kindred spirits insofar as they both desire what is absent, impossible and incalculable (Caputo 1997:2-3). For Derrida, ascribing transcendental significance to the signified can be seen as naïve objectivism, attaching transcendental significance status to the referent of language. Deconstruction proposes a theology without God or a transcendental signifier.

For Derrida, structure in language remains a socially constructed phenomena and the existence of language is not 
an invisible social reality. Meaning is a dialogic construction of shapes and constructs that creates meaning and representation of the text. For Bakhtin (quoted by Waghmare), the text is not a self-contained unit, nor is a language a strange object, but the creation of meaning is the dialogic interaction of multiple voices and approaches to discourse and interchanges. For Bakhtin, the text is the object of human sciences, whereas the knowledge of the subject is dialogical. Man's selfhood in generic terms is dialogical in nature. The (generic) essence of man, Bakhtin argues, is not an abstraction inherent in each separate individual, but the aggregate of social relationships. Dialogism for Bakhtin is based on the dialogue between the individual and the social, text and context, text and text, which clearly relates to the principles of intertextuality in the construction of meaning and representation of the other (Waghmare 2011:1-5).

Derrida's critique of the sign is based on the work of Husserl and his distinction between the indicative and expressive sign. According to Husserl an expressive sign is an intimate unity between the signifier and the signified and there is no distance between them. The indicative sign on the other hand points to that which it signifies and this remains at a distance from the signification process which does not provide equal meaning at the same time (Cassirer 2000:28) For Derrida there is no presence without absence. Signification is the presencing of the absence of the real.

Derrida's critique of the sign underpins his theory of deconstruction. The violent hierarchy between speech and writing from Plato to Saussure preoccupy Derrida's deconstructive activity in exposing Western discourse with the obsession of speech, as presence and writing mark a fall. Despite Derrida's radical introduction, which was imported from the Saussurian theory of meaning, Derrida cannot get away from the 'presence' to a ground of differences. Lucy (2004:111) observed that deconstruction would be impossible within the limits of the pre-Saussurian concept of the sign, because the difference between Saussure's signifier and the signified, as with the difference between langue and parole, is strongly grounded in a metaphysics of presence.

\section{Acknowledgements Competing interests}

The author declares that he has no financial or personal relationships that may have inappropriately influenced him in writing this article.

\section{References}

Allison, D.B., 1973, Speech, and phenomenon, Northwestern University Press, Evanston.

Bally, C. \& Sechehaye, A., 1986, Course in general linguistics: Ferdinand de Saussure, McGraw-Hill, New York.

Barthes, R., 1967, The death of the author, transl. A. Leavers, Smith \& Hill, New York. Barthes, R., 1977, Image-music-text, Fontana Press, London.

Barthes, R., 1979a, Elements of semiology, transl. A. Leavers, Smith \& Hill, New York. Barthes, R., 1979b, From work to text, textual strategies: Perspectives in poststructuralist criticism, Methuen, London.
Berman, A., 1988, From new criticism to deconstruction, University of Illinois Press, Chicago, IL.

Cahoone, L., 1996, From modernism to postmodernism, Blackwell, London.

Calcagno, A., 2009, 'Foucault, and Derrida: The question of empowering and disempowering the author', Springer 32(1), 33-51.

Canfield, K., 1993, The microstructure of logocentrism: Sign models in Derrida and Smolensky, University of Maryland Press, Bethesda, MD.

Caputo, J.D., 1997, The prayers and tears of Jacques Derrida: Religion without religion, Indiana University Press, Bloomington, IL.

Cassirer, E., 2000, A repetition of Modernity, State University of New York Press, New York.

Chandler, D., 2007, Semiotics, the basics, Routledge, London.

Culler, J., 1981, The pursue of signs: Semiotics, literature, deconstruction, Routledge \&Kegan Paul, London.

Culler, J., 1982, On deconstruction: Theory and criticism after structuralism, Routledge, London.

Degenaar, J., 1992, 'Deconstruction-the celebration of language', in B. Lategan (ed.), The reader and beyond: Theory and practice in South Africa reception studies, pp. 187-212, Human Sciences Research Council, Pretoria.

Derrida, J., 1966, Structure, sign, and play in the discourse of the human sciences, John Hopkins University Press, Baltimore, MD.

Derrida, J., 1976, Of grammatology, transl. G.C. Spivak, John Hopkins University Press, Baltimore, MD.

Derrida, J., 1977, 'Signature event context', transl. S. Weber \& J. Mehlman, Glyph 1 172-197.

Derrida, J., 1978, Structure, sign and play in the discourse of humanities. Writing and difference, transl. A. Bass, University of Chicago, Chicago, IL.

Derrida, J., 1981, Positions, University of Chicago Press, Chicago, IL.

Derrida, J., 1985, The ear of the other: Otobiography, transference, translation: Texts and discussions with Jacques Derrida, Schocken Book, New York.

Derrida, J., 1986, 'Racisms the Last', in H.L. Gates (eds.), Race, Writing and Difference, University of Chicago Press, Chicago.

Eco, U., 1976, A theory of semiotics, Indiana University Press, Bloomington, IL.

Ellis, J.M., 1989, Against deconstruction, Princeton University Press, Princeton, NJ.

Evans, C.J., 1991, Strategies of deconstruction, University of Minnesota Press, Minneapolis, MN.

Finnegan, R., 1992, Oral traditions and the verbal arts, Routledge, London.

Foucault, M., 1977, Language, counter-memory, practice: Selected essays and interviews, Cornell University Press, New York.

Hawkes, T., 1977, Structuralism and semiotics, Methuen, London.

Joyce, S., 2012, 'Feminist in flux', in S. Hogan (ed.), Revisiting feminist approaches to art theory, Berghahn Books, New York.

Kelber, W.H., 1990, 'The authority of the Word', Journal of the American Academy of Religion 58, 113-125.

Klages, K., 2012, 'Structuralism and poststructuralism', viewed 22 March 2015, from http://www.colorada.english2012klages/Derrida.html

Kristeva, J., 1980, Desire in language: A semiotic approach to literature and art, Columbia University Press, New York.

Lucy, N., 2004, A Derrida dictionary, Blackwell Publishing, London.

Marshall, I.H., 1979, New Testament interpretation: Essays principles and methods, Paternoster, Exeter.

Moore, S., 1994, Post-structuralism and the New Testament, Fortress Press, Minneapolis, MN.

Norris, C., 1982, Deconstruction theory and practice, Routledge, London.

Norris, C., 1987, Derrida, Fontana Press, London.

Rheinberger, H.J., 2008, 'Translating Derrida', The New Centennial Review 8(3), 175-187. http://dx.doi.org/10.1353/ncr.0.0045

Rouseau, J.J., 1986, On the origin of language, University of Chicago Press, Chicago, IL. Royle, N., 1995, After Derrida, Manchester University Press, Manchester.

Shepherd, R.J., 2007, 'Perpertual unease of being at ease? Derrida Daoism and the metaphysics of presence', Philosophy of East and West 57(2), 227-243. http:// dx.doi.org/10.1353/pew.2007.0025

Spivak, G.C., 1976, Of grammatology, Johns Hopkins University Press, Baltimore, MD. Taylor, M., 1984, A postmodern A/theology, University of Chicago Press, Chicago, IL.

Trifonas, P.P., 2001, 'Teaching the other/writing the other: Derrida and the ethics of the ethnographic text', Social Semiotics 1(3), 325-341. http://dx.doi.org/10.1080/ 10350330120032539

Tull, P.K., 1999, 'Rhetoric criticism and intertextuality', in S. Mc Kenzie \& S. Haynes (eds.), To each its own meaning, rev. edn., pp. 156-180, Westminister, Louisville, KY.

Tull, P.K., 2000, 'Intertextuality and the Hebrew Scriptures', Currents in Research: Biblical Studies 8(1), 59-90.

Turner, D., 2004, Faith, reason and the existence of God, Cambridge University Press, London.

Waghmare, P.R., 2011, 'Mikhail Bakhtin's dialogism and intertextuality: A perspective', Indian Streams Research Journal 1(5), 1-5. 